\title{
Localization of Marxism in China: History, Theory and the Challenge
}

\author{
Peng $\operatorname{Li}^{1}$ \\ ${ }^{1}$ College of Marxism, Northwestern Polytechnical University, Xi'an, China \\ Correspondence: Peng Li, College of Marxism, Northwestern Polytechnical University, Xi'an, China. Tel: \\ 150-290-90163. E-mail: lipeng@nwpu.edu.cn
}
Received: September 21, $2018 \quad$ Accepted: October 8, $2018 \quad$ Online Published: November 30, 2018
doi:10.5539/jpl.v11n4p89
URL: https://doi.org/10.5539/jpl.v11n4p89

The research is financed by the ministry of education of youth fund project in 2016 (project number: 16 YGC710022).

\begin{abstract}
Marxism is the science of universal standard. The truth, practicality, scientific of Marxism has been proved by history. But with the development of practice, the development of Marxist theory itself is facing a new opportunity, also faced with unprecedented challenges. How to effectively cope with the challenges? Such as: Is communism a utopia? The labor theory of value is effective? Socialist country is democracy? And so on. All these problems are the socialist system and Marxist must think and answer.

As a Marxist, how to truly stand in the position of Marxism, using the Marxist method and point of view to observe the social and economic development and the progress of human civilization and world history, is the problem of contemporary Marxists has to think about. Or it will lose vitality, and will be out of date, and possible failure. The most familiar example is the socialist power caused by the collapse of the Soviet Union and its consequences.

As important heritage and development of Marxist theory, the Communist Party of China has always been guided by the Marxism theory, whether in revolution, construction and reform, or the governing principle politics today. Can say, not only accumulated a very valuable historical experience, but also enriched and developed Marxism, the Communist Party of China have a say in the history of Marxist development.

So, we need to discuss three questions, the effectiveness of the Marxist theory, and understanding of Marxist trajectory of the Communist Party of China, the challenge for the Marxism theory and how to deal with.
\end{abstract}

\section{Keywords:}

Sinicization of Marxism; History; Theory; Challenge

\section{The Historical Logic of Sinicization of Marxism}

\subsection{The Early Spread of Marxism in China}

The history of recognition of Marxism of the Communist Party of China is back to the beginning of the 20th century. After more than half a century of debate and controversy and struggle, all kinds of ideological, such as westernization movement and the die-hards; the reformists and royalist; revolutionaries and reformists, began to spread in China. In order to solve the problem of China's modernization, which will include Marxism. Marxism was introduced into China in the late 19th century early 20th century. So, a western theory is how to come to China? Seeking truth from facts, Marxism was introduced into China, once was welcomed by the clairvoyance including Sun Zhongshan.

The current scholars have consensus: Marxism spread mainly has three sources, Japan, Europe (France), and the Soviet Union. Some scholars believe that Japan is the main channel; the Soviet Union is later. Which for China to spread Marxism? Mainly professional revolutionaries and groups of students to study abroad have been attracted to the truth, to spread scientific theory. Marxism is the science of revolution and is the scientific revolution. The most important is to focus on how to implement the revolution, but in fact, the early Chinese Marxists overall understanding is not clear. Don't liking early Russian Marxists, it began to accept and spread on the basis of the further study of Marxism, but urgent need to study. For the sake of the revolution at that time, 
fighting for national independence, it urgently needs a scientific theory to guide. At that time Marxism theory through simple propaganda slogans and banners to mobilize the masses, practice had proved that revolutionary effect was good. But subsequent also had some problems, Such as the understanding of many problems in theory is not clear, which lead to go some detours after the founding of new China. This has led to a problem: how Marxism sinicization.

\subsection{Understanding and Thinking to Sinicization of Marxism in China of the Early Chinese Communists}

Revolution must have scientific theoretical guidance for revolution. Therefore, the Chinese found a Marxist. But with the correct theory instruction, revolution also had failed? Why? The early Communists of the communist party of China have been thinking on this question, such as Li Dazhao, Chen Duxiu, etc. They have realized the revolution should be combined with China's actual. Another problem, had the Communist party of China put forward sinicization of Marxism only in Yan an period? The answer is no. How is the sinicization of Marxism to put forward? How had the Communist party of China critically absorbed "sinicization" ideological trend and put forwarded his idea? In fact, the sinicization of Marxism, which was put forward, had experienced a historical process. What is the cognition trajectory of the Communist Party of China? This is about to say to the Opium War, which had a significant impact in Chinese modern history. A lot of people in a certain sense think the Opium War as a military, political war. In fact, it is far more than that, the influence of a deeper understanding, Should be looking at from a cultural perspective. Dialectical materialism and historical materialism think that social being determines social consciousness; the economic base determines the superstructure. But in a certain historical condition, the latter will react on the former to affect the process of human history. After the Opium War, some people advocated wholesale westernization; learned the western education system; denied all of China, including traditional culture, system design, etc.; Some people claimed to standard culture, traditions to reject the era spring tide, and they thought everything outside was not good. Of course, there was a small part of clairvoyance to realize the importance of combining. In the face of Marxism, a foreign theory, also a kind of exotic culture, the Chinese also experienced a tortuous process. From the beginning Marxism was not be valued; don't be understood, and has been selected by the Chinese people later.

Since modern times, western theory, thoughts gradually introduced into China, people in the study, according to the process, slowly found, many theories of the west, practice in China is not so helpful. This aroused people's thinking. Because the country is different, idea and practice no matter how good can't copy. It can be said that before and after the "May 4th", a consensus has emerged among people in China ideological circle, namely regardless of what kind of theory, the introduction of foreign will strive to combine with the actual situation of China.

But looked from the practice, in retrospect, we can see, this time the progress of the Chinese revolution is not very desirable. After the founding in 1921, the Labor movement developing rapidly, but the impact is limited. Until 1927, the three major uprising by the communist party of China, there is no doubt for its historical contributions. But during this period, basically the path of the Chinese revolution is still basically the Soviet Union road. That is encircling the rural from the cities. Such as the Nanchang uprising, the autumn harvest uprising, Guangzhou uprising, they are against the big city. Why is this case? Personally, I think this period the communist party of China on the whole level of understanding of Marxism is not high. Their cognition of sinicization of Marxism is the theoretical, ideological, is just a preliminary of the idea of combining, and hasn't become the guiding ideology or unified ideology. Of course, revolutionary practice will not change.

So, we speak this period of sinicization of Marxism, or "combined" thought is not conscious, not form a unified understanding in the party. So what time to the sinicization of Marxism has become the consensus of the party? This is to the Anti-Japanese War period, and it must be said to the master of sinicization of Marxism, Mao Zedong.

\subsection{Maturation of Localization of Marxism in China}

We always speak the period from the late Agrarian Revolutionary War to the Anti-Japanese War is the mature of the communist party of China during. In fact, since the ZunYi Meeting, the Communist Party of China had begun to independent of revolution. Further in-depth understanding of Marxism sinicization is the one of the important sign of maturity of Communist party of China. Marxism in this period is no longer just thought of something, but more touched on practical problems, and began to show the importance of sinicization of Marxism. During this period, sinicization of Marxism had risen to theoretical. Mao Zedong in "on a new stage" political report, put forward the sinicization of Marxism, and explained the basic connotation of sinicization of Marxism: "no Marxism in the abstract, only specific Marxism. The so-called Marxism is through the national form of Marxism; is the application of Marxism to the struggle of China's specific environment, rather than 
application in the abstract. "In the Seven of the Communist Party of China in 1945, Marxism ideas become the consensus of the whole party through Yan 's Rectification Movement. From 1938 to now, Marxism finally married fruits, this is the first theoretical result of sinicization of Marxism, Mao Zedong thought.

Sinicization of Marxism is not plain sailing. It also faced the party dogmatism. Dogmatic Such as Wang Ming opposed proposition of sinicization of Marxism. After 1949, China began to economic development. Since roughly 30 years, almost all books, documents, articles were no longer appear the words "Marxism", but also used a unified formulation of universal truth with concrete practice. But if for exploration, from the subtle change of such a formulation, we can see that change has an important international background. What is the important international background? That was in June 1948, the Communist Party intelligence agency passed a resolution, condemning the communist Yugoslavia so-called nationalism, against the Soviet Union and the tendency of capitalism. The central committee of the Communist Party of China may consider that the two formulations of "Marxism" and "MAO Zedong thought" were liable to be misinterpreted as so-called nationalism. In order to strive for the support and help of the Soviet Union, so the changes in the formulation. So, from here we can see, sinicization of Marxism is put forward to break the bondage of the communist international and the Soviet Union had an important relationship.

Summary of more than 90 years of history of Marxism, it proved that only by constantly emancipating the mind, seeking truth from facts, adhere to the scientific view of Marxism, to put the cause of China's revolution, construction and reform forward.

\section{How to Think about the Theoretical Achievements of Localization of Marxism in China}

Xi Jinping said: "our party was able to test after suffering gets, the key is to constantly to practice innovation and theoretical innovation. Marxism must be combined with China's actual, to realize the sinicization and popularization. "Again at the same time he points out: "in the face of the new times characteristics and practical requirements, Marxism is facing sinicization, modernization and popularization further."

First, the development of Marxism. Marxism founder told us: "our theory is the development of the theory, rather than have to back to mature and mechanically repeated dogma. " "Marx's whole worldview is not doctrine, but method. "Anytime to transfer to the historical condition at that time, as "the communist manifesto" said. This shows that Marxism is not a dogma, but a method; it is the truth but cannot copy; it must combine with the national conditions of different countries to externalize, nationalization and localization. Since the birth of Marxism, the understanding of Marxism is divided. The Soviet Union, China, Japan, Germany, Britain, etc. in understanding of Marxism is different. Understanding of Marxism in China by foreign ways, especially the later Marxism for the Soviet Union. This is double influence on the development of Chinese society, both the good side, also has disadvantages. Although different countries, in general, have different understanding, practice and ways of Marxism, but the most basic value orientation is the same, Such as the realization of communism, everyone free and comprehensive development, the working class leadership, etc. The practical experience of different countries provides a concrete and rich material for the 21st century the development of Marxism.

Second, Marxist nationalization. The so-called Marxism is to make the basic principle of Marxism with the concrete practice of China's specific combination, to make Marxism with China's national characteristics and national style to be able to the scientific theory of Chinese to guide revolution and construction. First, the sinicization of Marxism is to use Marxism to solve practical problems of the revolution, construction and reform of China. Second, Marxism is to make historical experience and practical experience of Chinese revolution, construction and reform to promote to theory. Third, sinicization of Marxism is that the Marxism is rooted in the Chinese excellent culture.

Third, the relationship between the two great theoretical achievements. How to think of relationship between MAO Zedong thought and theoretical system of socialism with Chinese characteristics? It is about us asking for historical and realistic problems. First, MAO Zedong thought is the important thought origin of theoretical system of socialism with Chinese characteristics. Second, the system of theories of socialism with Chinese characteristics under the new historical conditions further enriches and develops MAO Zedong thought. Once again, MAO Zedong thought and theory system of socialism with Chinese characteristics is the use and development of Marxism-Leninism in China. Thus, the correlation is not divided; more is not contradictory relations. They are inheritance and development and belong to the achievements of sinicization of Marxism theory.

On the one hand, and never can be split between the two, even the other side, nor entirely equivalent as a theory, which are theoretical achievements of sinicization of Marxism. Otherwise, will not be able to correctly understand the history of the communist party of China. Already can't use the former negate the latter, and vice 
versa. We should guard against the erroneous tendency.

\section{The Real Challenge of Localization of Marxism in China}

History and the practice have proved that Marxism must be localization, nationalization and embodiment. Otherwise it is no vitality. This conclusion not only conforms to the requirements of the development of Marxist theory itself, and is the important basis of guiding the practice. It is also conclusions from the historical experience of Chinese revolution. The largest scientific Marxism, is the development, is not a zombie doctrine. The communist party of China pays attention to combine Marxism with Chinese reality, solves the problems of the different developmental stages, such as the revolution, construction and reform and opening up today, this is the most important valuable experience in China's development. Marxism in contemporary China is faced with new challenges, mainly embodied in the following aspects:

First, look at how the science of Marxist theoretical innovation. Marxism, Leninism, MAO Zedong thought and socialism with Chinese characteristics, is a kind of what kind of relationship? From find according to Marxist theory is a new copy, summarized the experience of China's practice and to Marx, such as "Shared development" concept, how to deal with and answer.

Second, how to better respond to that Marxism is not in conformity with the national conditions of China. The method of class analysis is one of the major means of Marxism. Since reform and opening up, China is the appearance of many new classes. How to realize these classes, can also use Marxism to analyze? Again for instance, the problem about tension between theory of identity and the ruling party's credibility. Whether Marxism is suitable for China's national conditions? 100 years ago, Marxism was introduced into China, the problem has appeared, later appeared several times bigger controversy.100 years ago, Marxism was introduced into China, the problem had appeared, later appeared several times bigger controversy. At the time of Marxist made a strong response. Li Dazhao is the important one debate who studied in Waseda University. He responded to the challenge of the westernization theorists Hu Shi. Looking from the reality, 100 years later, the problem now appears again or hidden or appeared.

Third, how to timely resolve the Marxist discourse marginalized. Marxism as a guide the scientific theory of the Chinese revolution has been proved by history, but in today's reform and opening up, the Marxist discourse does exist marginalized. The communist party of China has begun to realize and solve the problem. Xi Jinping in philosophy and social science work symposium speech pointed out that: "in the practical work, in some areas of Marxism marginalized, empty generalization, label." How to solve the problems? In 2012, after the 18th National Congress of the Communist Party of China (CPC) , so to speak, the CPC central committee started attaches great importance. And there are a series of supporting policies, real Marxism to its rightful place.

\section{Conclusion}

We feel confident is that the communist party of China and Marxism theoretical workers have begun to change the state of previous research, especially since the 18th National Congress of the Communist Party of China (CPC) in 2012. Don't focus on China, Marxist theory has no future. I quite agree with this sentence that dealing with the problems of China needs to depend on oneself. Now is not closed more than 170 years ago, but in a more inclusive, innovation development as the guidance. Marxism is truth. Truth is not afraid of challenges; does not shy away from questions, and is not allowed to distort. Sinicization of Marxism had been questioned, which is put forward the international background of Marxist sinicization. The Soviet Union accused China of exploration in the way of its own national conditions to "narrow nationalism", lowering the position of the Marxist internationalism. Therefore, in the late $50 \mathrm{~s}$, the Soviet Union newspapers no longer mentioned, "MAO Zedong thought". Marxist sinicization, however, is not isolated, from the world, self-sealing; makes narrow nationalism or regional communism.

\section{References}

Big important literature compilation of (in) since the eighteenth. (2017). Central literature publishing house, Beijing.

Xi, J. P. (2017a). Xi Jinping talk about governing (Vol. 2). Foreign languages publishing house, Beijing.

$X i, J . P .(2017 b)$. Redefining a well-off society in an all-round way and seize the new era of the great victory of socialism with Chinese characteristics. People's publishing house, Beijing. 


\section{Copyrights}

Copyright for this article is retained by the author(s), with first publication rights granted to the journal.

This is an open-access article distributed under the terms and conditions of the Creative Commons Attribution license (http://creativecommons.org/licenses/by/4.0/). 